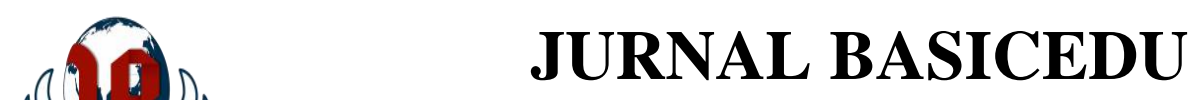

Volume 5 Nomor 4 Tahun 2021 Halaman 2530 - 2540

Research \& Learning in Elementary Education https://jbasic.org/index.php/basicedu

\title{
Pengembangan Media Pembelajaran Video Animasi En-Alter Sources Berbasis Aplikasi Powtoon Materi Sumber Energi Alternatif Sekolah Dasar
}

\author{
Fifit Fitria Dewi $^{1 \bowtie}$, Sri Lestari Handayani ${ }^{2}$ \\ Universitas Muhammadiyah Prof. DR. HAMKA, Indonesia ${ }^{1,2}$ \\ E-mail: fifit.fitriadew15@gmail.com ${ }^{1}$, srilestarih@uhamka.ac.id ${ }^{2}$
}

\begin{abstract}
Abstrak
Perkembangan zaman semakin modern, guru dituntut berinovasi mengenai media pembelajaran. Penelitian ini bertujuan untuk mengetahui kelayakan media pembelajaran video animasi berbasis powtoon, mengetahui respon siswa kelas IV pada pembelajaran IPA materi sumber energi alternatif. Penelitian ini dilakukan di SDN Sukamakmur 03 tahun ajaran 2020/2021 pada semester genap. Metode penelitian yang digunakan adalah penelitian dan pengembangan atau Research and Development (R\&D). Model yang digunakan dalam penelitian ini yaitu addie yang memilki 5 tahapan yaitu: analysis, design, development, implementation, and evaluation. Teknik pengumpulan data pada penelitian ini menggunakan kuesioner dan lembar instrument yang digunakan yaitu angket dengan menggnakan skala likert. Uji produk dilakukan oleh dua ahli materi dan dua ahli media, serta siswa merupakan responden pada media yang dikembangkan. Media pembelajaran ini di uji cobakan kepada 18 siswa sebagai uji terbatas. Hasil penelitan ini menunjukkan ahli materi memperoleh nilai skor sebesar $85,88 \%$, ahli media sebesar $88,3 \%$, dan siswa memperoleh skor $86,9 \%$ dengan kategori layak digunakan. Maka dapat disimpulkan bahwa media pembelajaran video animasi berbasis powtoon layak digunakan di kelas IV pada pembelajaran IPA materi sumber energi alternatif.
\end{abstract}

Kata Kunci: media pembelajaran, powtoon, addie, en-alter sources.

\section{Abstract}

The purpose of this study was to determine the feasibility of animation video based on Powtoon in science learning about alternative energy sources in the fourth grade of elementary school. This type of research is Research and Development $(R \& D)$ and uses the ADDIE development model. The ADDIE model consists of a). analysis, $b$ ) design, $c$ ). development, $d$ ). implementation, e). evaluation. The learning media developed were analyzed by a team of experts and the subjects of this research were media experts, material experts, and fourth grade elementary school students. This research was conducted at SDN Sukamakmur 03 with a total of 18 students. The data collection technique carried out in this study used a questionnaire and the instrument sheet used was a questionnaire using a Likert scale. Data analysis in this study is quantitative and descriptive data analysis. The validity test was carried out by two material experts, namely material experts who obtained an average score of $85.8 \%$, media experts obtained an average score of $88.3 \%$ with a suitable category for use, and student responses obtained a score of $86.9 \%$.

Keywords: learning media, powtoon, addie, en-alter sources.

Copyright (c) 2021 Fifit Fitria Dewi, Sri Lestari Handayani

Corresponding author :

Email : fifit.fitriadew15@gmail.com

DOI : https://doi.org/10.31004/basicedu.v5i4.1229

ISSN 2580-3735 (Media Cetak)

ISSN 2580-1147 (Media Online)

Jurnal Basicedu Vol 5 No 4 Tahun 2021

p-ISSN 2580-3735 e-ISSN 2580-1147 
2531 Pengembangan Media Pembelajaran Video Animasi En-Alter Sources Berbasis Aplikasi Powtoon Materi Sumber Energi Alternatif Sekolah Dasar - Fifit Fitria Dewi, Sri Lestari Handayani

DOI: https://doi.org/10.31004/basicedu.v5i4.1229

\section{PENDAHULUAN}

Seiring berkembangnya zaman, perkembangan teknologi pun semakin berkembang pesat. Perkembangan teknologi saat ini memberikan pengaruh diberbagai bidang. Bidang pendidikan menjadi salah satunya. Hal ini sejalan dengan penelitian Yuanta (2019:92) menyatakan bahwa perkembangan teknologi memberikan pengaruh bagi dunia pendidikan khususnya dalam media pembelajaran yang digunakan dalam proses pembelajaran. Pada era modern ini, para guru diharuskan selalu berinovasi mengenai media pembelajaran yang digunakan. Media pembelajaran adalah alat bantu, bahan atau teknik yang memungkinkan digunakan dalam proses pembelajaran berlangsung agar proses interaksi komunikasi antara guru dengan peserta didik dapat berlangung secara tepat Khuluqo (2017:144), Yuanta (2019:92). Menurut Asyhari (2016) media pembelajaran merupakan bagian integral dalam sistem pembelajaran. Tafonao (2018:103) memaparkan bahwa peranan media pembelajaran sangatlah penting bagi guru dan siswa, karena itu media pembelajaran menjadi salah satu faktor keberhasilan dalam proses belajar siswa dan melalui media siswa dapat terlibat aktif sehingga termotivasi untuk belajar (Fadhli, 2015:24).

Penggunaan alat atau pemanfaatan media pembelajaran dalam proses belajar mengajar juga dapat membangkitkan keinginan dan minat bagi siswa, serta membangkitkan motivasi belajar siswa bahkan dapat membawa pengaruh terhadap psikologis pada siswa. Selain dapat meningkatkan motivasi dan minat belajar siswa, penggunaan atau pemanfaatan media pembelajaran juga dapat meningkatkan pemahaman siswa terhadap pelajaran sehingga dapat membantu proses pembelajaran menjadi lebih efektif dalam penyampaian pesan dan isi pelajaran tersebut Hamalik dalam Suryani, (2016:186). Menurut Rejeki dkk, (2020:338) pemanfaatan media pembelajaran dapat berhasil dengan baik ketika siswa memanfaatkan semua alat inderanya.

Berdasarkan observasi yang dilakukan peneliti di kelas IV SDN Sukamakmur 03 yaitu belum semua guru menggunakan media pembelajaran. Guru cenderung hanya memberikan materi melalui WhatsApp Group kelas. Awalia dkk (2019:50) berpendapat kurangnya pemanfaatan media pembelajaran menjadi salah satu faktor rendahnya pemahaman siswa terhadap materi yang dibahas. Selain itu, masih banyak siswa yang kurang mengerti materi IPA. IPA menjadi salah satu materi pelajaran yang memiliki tingkat pemahaman yang tinggi salah satunya yaitu sumber energi alternatif. Siswa cenderung menghafal materi dari buku tema yang ada tanpa memahaminya dan didukung dengan minimnya gambar sehingga siswa merasa bosan. Menurut Mulyasa dalam Awalia dkk, (2019:50) meyatakan proses pembelajaran harus melibatkan siswa agar mampu bereksplorasi dalam membentuk kompetensi dengan menggali potensi. Untuk itu, sangat diperlukan sekali peran guru dalam mengembangkan kreativitas pada saat pembelajaran berlangsung.

Proses pembelajaran berlangsung guru dituntut untuk menciptakan pembelajaran yang kreatif, efektif dan efisien. Kreativitas guru dapat dilakukan dengan cara membuat media pembelajaran yang berguna untuk meningkatkan kualitas pembelajaran. Media yang digunakan disesuaikan dengan karakteristik siswa itu sendiri dan materi yang diberikan Firdaus Ahmad, (2021:2009). Salah satu media pembelajaran yang dapat digunakan yaitu media pembelajaran video. Video animasi menjadi media yang paling efektif dalam proses pembelajaran dan dapat memberikan sebuah pengalaman tersendiri bagi peserta didik. Hal ini didukung dengan pendapat Garsinia dkk (2020:45) dan Hakim, (2019:309) bahwa media video animasi membantu proses pembelajaran dan materi yang terdapat dalam video menjadi daya tarik siswa sehingga siswa mudah memahami materi yang disampaikan dan mempermudah guru dalam menyampaikan materi yang hendak dicapai. Terlebih pada kondisi pandemic ini sangat diperlukan media video untuk membantu guru dalam proses pembelajaran yang dilakukan secara daring. Penggunaan media pembelajaran diharapkan dapat mempermudah guru dalam menyampaikan materi dan penguasaan materi Aprianty \& Wiyono, (2021:3). Penggunaan media dalam pembelajaran mengalami banyak perubahan mulai dari bentuknya yang awalnya berbentuk fisik, hingga sekarang sudah banyak media pembelajaran berbentuk digital atau online. 
Pada kondisi saat ini, pemanfaatan media pembelajaran video sangat dibutuhkan para tenaga pendidik agar proses pembelajaran bisa terlaksana dengan lebih mudah. Hal tersebut sejalan dengan pernyataan Wisada (2019:141) yang menyatakan bahwa pemanfaatan media sangat penting bagi guru untuk menunjang proses pembelajaran karena dapat meningkatkan daya tarik peserta didik dalam belajar sehingga tingkat pemahaman dapat meningkat. Proses pemahaman terhadap suatu materi pembelajaran dapat menambah prestasi siswa lebih baik.

Media pembelajaran video yang tepat untuk digunakan salah satunya yaitu berbasis aplikasi Powtoon. Powtoon merupakan sebuah program aplikasi berbasis web yang bersifat online dan berfungsi sebagai aplikasi pembuat video animasi untuk presentasi dan membantu memberikan penjelasan materi yang sulit dipahami Ranie (2018:146). Kelebihan dari aplikasi Powtoon yaitu mudah digunakan karena hasilnnya berupa video serta kemudahan dalam membuat animasi-animasi yang dapat menarik minat siswa sekolah dasar dan mudah diakses kapan dan dimana pun. Selain itu, Powtoon juga dapat menyediakan musik, pengguna dapat menambahkan suara (record), animasi tulisan tangan, dan menyediakan efek transisi disertai berbagai macam warna yang menjadi pembelajaran lebih menarik dan terlihat hidup. Hal ini didukung dengan pendapat Sutarsih \& Hermanto (2019:3) Powtoon memiliki animasi-animasi yang menarik yang dapat dikreasikan sehingga menjadi sebuah produk yang cukup menarik. Tujuan penelitian ini untuk mengetahui kelayakan media pembelajaran video animasi berbasis powtoon pada pembelajaran IPA materi sumber energi alternatif di kelas IV sekolah dasar.

\section{METODE PENELITIAN}

Peneliti menggunakan metode research and development (R\&D). Model yang digunakan artinya model ADDIE yang mempunyai lima tahapan yaitu: analysis, design, development, implementation, and evaluation, tetapi pada penelitian ini peneliti mebatasi sampai dengan tahapan implementation. Tahapan pertama yaitu analysis, peneliti melakukan observasi di SDN Sukamakmur 03, setelah melakukan observasi peneliti mengetahui yang diperlukan pada proses pembelajaran pada kelas IV yaitu sebuah media pembelajaran. Kebutuhan dilihat dari karakteristik peserta didik itu sendiri yang akan disesuaikan dengan produk yang dikembangkan yaitu media pembelajaran berupa video berbasis perangkat lunak powtoon, kemudian menganalisis materi pembelajaran yang akan dipergunakan serta analisis perangkat yang akan digunakan buat membuatkan produk.

Tahapan selanjutnya yaitu tahapan design, pada tahapan ini peneliti menyiapkan konsep yang akan dikembangkan seperti storyboard, penyusunan materi dan naskah, pengumpulan gambar, font, ukuran tulisan, dan musik. Tahapan berikutnya yaitu tahap development, pada tahapan realisasi dari tahapan sebelumnya yaitu tahapan desain. Peneliti mengaplikasikan desain yang sudah didesain dari storyboard ke dalam komputer seperti gambar, animasi-animasi bergerak, musik, penyusunan materi dan naskah. Pada tahapan development juga dilakukan uji validasi oleh tim ahli untuk mengetahui kelayakan sebuah produk yang telah dikembangkan dan melakukan perbaikan produk sesuai dengan saran tim ahli sebelum diterapkan. Pada tahapan implementation peneliti melakukan implementation pada siswa kelas IV sekolah dasar di SDN Sukamakmur 03 dengan jumlah 18 siswa.

Model ADDIE adalah menjadi salah satu model desain yang paling efektif dan efisien, setiap langkah pengembangan pembelajaran memperhatikan tahapan dasar sistem pembelajaran Cahyadi (2019:36). Model ADDIE dilakukan secara berurutan dan sistematis dalam upaya pemecahan masalah dalam menggunakan media belajar sesuai karakteristik siswa Wisada (2019:141). Hasil produk pada penelitian ini adalah video pembelajaran berbantuan software powtoon. Teknik pengumpulan data yang dilakukan dalam penelitian ini menggunakan kuesioner dan lembar instrument yaitu angket. Instrument pengumpulan data yang digunakan yaitu instrumen validasi ahli dan tanggapan siswa setelah uji coba media pembelajaran. Validasi ahli terdiri 
2533 Pengembangan Media Pembelajaran Video Animasi En-Alter Sources Berbasis Aplikasi Powtoon Materi Sumber Energi Alternatif Sekolah Dasar - Fifit Fitria Dewi, Sri Lestari Handayani

DOI: https://doi.org/10.31004/basicedu.v5i4.1229

dari dua ahli materi dan dua ahli media. Validasi produk yang telah dilakukan oleh ahli materi dan ahli media untuk menentukan kevalidan atau kelayakan media yang telah dibuat.

Penilaian produk yang diperoleh dari hasil uji validasi ahli materi dan ahli media dilakukan menggunakan skala likert. Skor pada setiap kriteria yaitu 5 (Sangat Setuju), 4 (Setuju), 3 (Netral), 2 (Tidak Setuju), 1 (Sangat Tidak Setuju). Teknik analisis data yang digunakan pada penelitian ini adalah analisis data kuantitatif dan deskriptif. Data kuantitatif dapat dilihat pada penilaian produk yang ditelah dinilai oleh validator ahli, sedangkan data deskriptif dapat dilihat pada kritik dan saran atau masukan yang diberikan oleh validator ahli.

Validasi kelayakan produk pada penelitian ini menggunakan teknik deskkriptif presentase dengan rumus berikut;

$$
\text { Persentase skor }=\frac{\sum \text { skor perolehan }}{\sum \text { skor maksimum }} \times 100 \%
$$

Setelah memperoleh dari data skor dapat diukur dengan kriteria kelayakan media pembelajaran dapat dilihat pada tabel 1 .

Tabel 1. Rentang presentase dan Kriteria Kelayakan Media

\begin{tabular}{cc}
\hline Interval & Kriteria \\
\hline $85 \%-100 \%$ & Sangat Baik \\
\hline $69 \%-84 \%$ & Baik \\
\hline $53 \%-68 \%$ & Cukup \\
\hline $37 \%-52 \%$ & Kurang Baik \\
\hline $20 \%-36 \%$ & Tidak Baik \\
\hline Garsinia dkk., 2020:46)
\end{tabular}

\section{HASIL DAN PEMBAHASAN}

Penelitian ini mengembangkan media pembelajaran video animasi berbasis powtoon pada materi sumber energi alternatif kelas IV Sekolah Dasar di SDN Sukamakmur 03. Penelitian yang dilakukan menggunakan model addie, yaitu analysis, design, development, implementation, and evaluation, namun pada penelitian ini peneliti melakukan sampai dengan tahap implementation.

Tahapan Analysis yang dilakukan peneliti yaitu menganalisis kebutuhan siswa mengenai masalah apa yang dihadapi siswa, dan masalah yang dihadapi siswa yaitu diperlukan adanya sebuah media pembelajaran yang efektif. Hal yang harus diperhatikan pada tahapan analisis kebutuhan yaitu dilihat dari karakteristik siswa itu sendiri, karena akan disesuaikan dengan produk yang akan dikembangkan yaitu media pembelajaran berupa video berbasis aplikasi powtoon, kemudian menentukan tujuan pengembangan produk yakni agar mempermudah siswa dan guru dalam proses pembelajaran berlangsung serta mengumpulkan materi yang akan digunakan, dan mengidentifikasi perangkat keras dan lunak yang digunakan.

Tahapan Design peneliti menyiapkan konsep produk yang akan dikembangkan seperti penyusunan materi dan naskah, pengumpulan animasi (gambar dan desain), musik dan storyboard. Melalui tahapan desain, produk yang akan dikembangkan terjamin kualitasnya Faisal (2016). Storyboard media pembelajaran video animasi berbasis powtoon dapat dilihat pada gambar dibawah ini. 
2534 Pengembangan Media Pembelajaran Video Animasi En-Alter Sources Berbasis Aplikasi Powtoon Materi Sumber Energi Alternatif Sekolah Dasar - Fifit Fitria Dewi, Sri Lestari Handayani DOI: https://doi.org/10.31004/basicedu.v5i4.1229

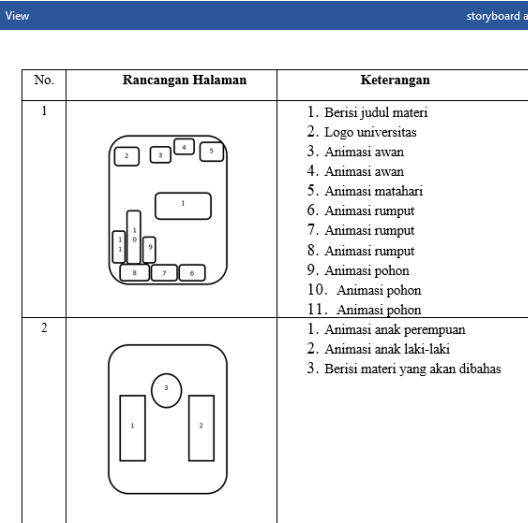

Gambar 1. Storyboard scene 1 dan 2

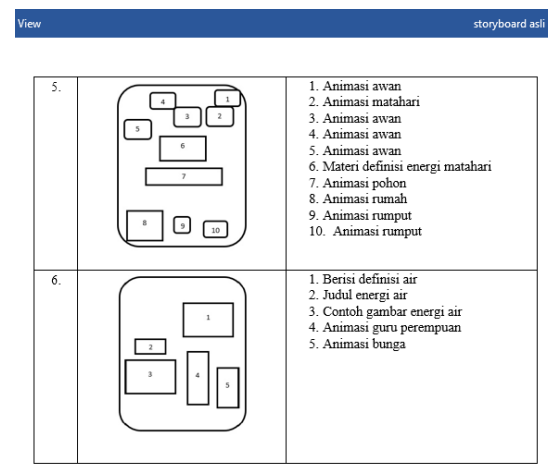

Gambar 3. Storyboard scene 5 dan 6

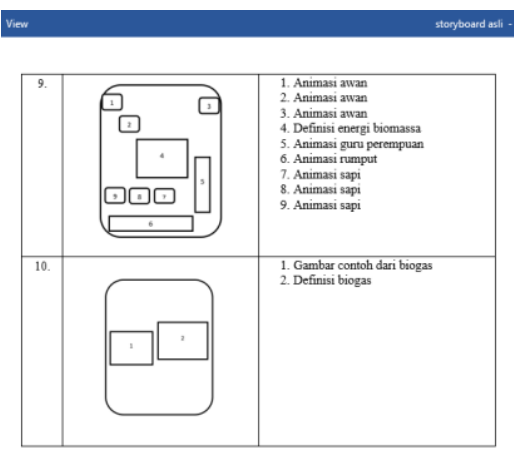

Gambar 5. Storyboard scene 9 dan 10

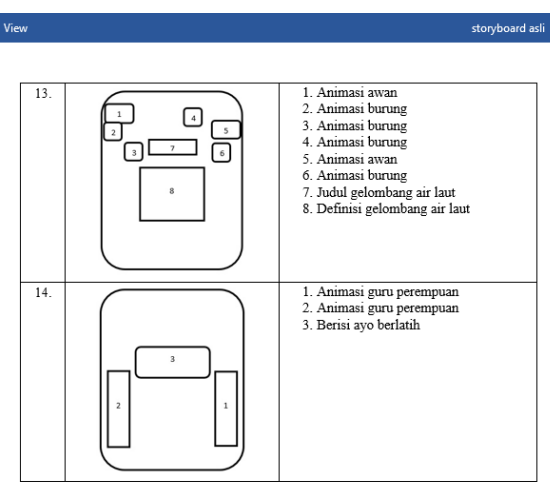

Gambar 7. Storyboard scene 13 dan 14
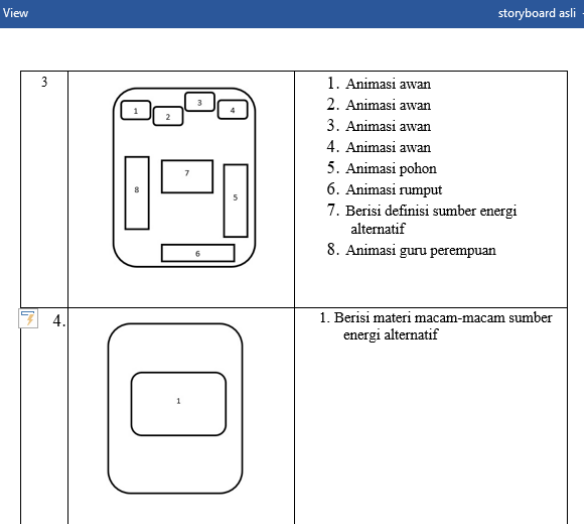

Gambar 2. Storyboard scene 3 dan 4

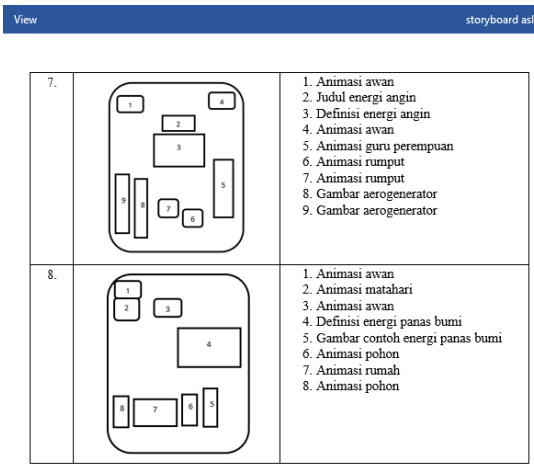

Gambar 4. Storyboard scene 7 dan 8

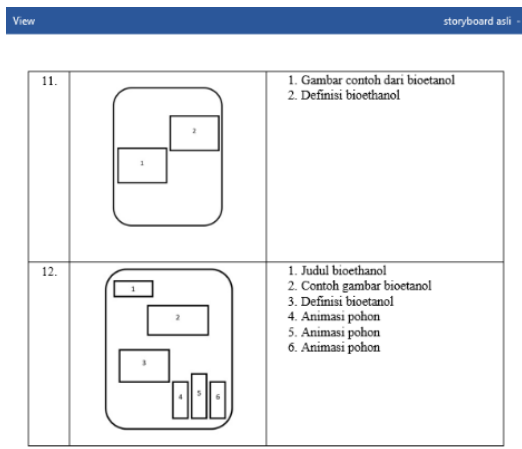

Gambar 6. Storyboard scene 11 dan 12

View
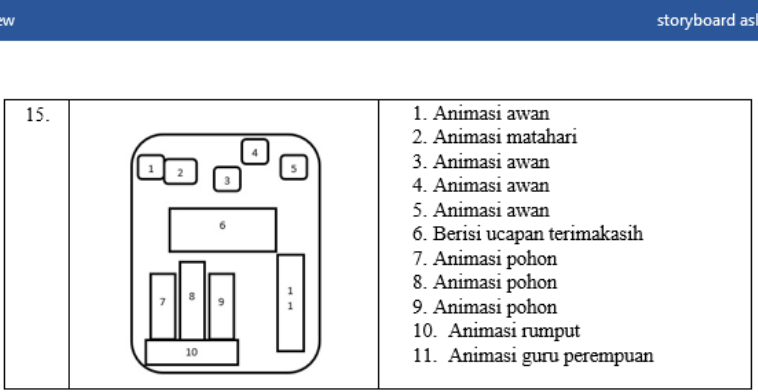

Gambar 8. Storyboard scene 15

Jurnal Basicedu Vol 5 No 4 Tahun 2021 p-ISSN 2580-3735 e-ISSN 2580-1147 
2535 Pengembangan Media Pembelajaran Video Animasi En-Alter Sources Berbasis Aplikasi Powtoon Materi Sumber Energi Alternatif Sekolah Dasar - Fifit Fitria Dewi, Sri Lestari Handayani

DOI: https://doi.org/10.31004/basicedu.v5i4.1229

Tahapan Development atau biasa dikenal dengan tahap pengembangan. Irwan, (2014:6) menyatakan bahwa tahap development adalah komponen yang telah dibuat sebelumnya dari tahap analisis dan desain dikumpulkan menjadi satu dan diubah dalam bentuk media yang siap pakai. Pada tahap ini peneliti merealisasikan dari tahapan desain yang telah dibuat sebelumnya, kemudian peneliti mengaplikasikan desain storyboard yang telah dibuat ke dalam komputer di mulai dengan pemilihan warna, menentukan ukuran tulisan dan bentuk font, penentuan dan peletakan bentuk animasi, isi materi, dan musik. Pengembangan media pembelajaran video animasi berbasis powtoon dapat dilihat pada tabel 2 .

Tabel 2. Produk media pembelajaran berbasis powtoon

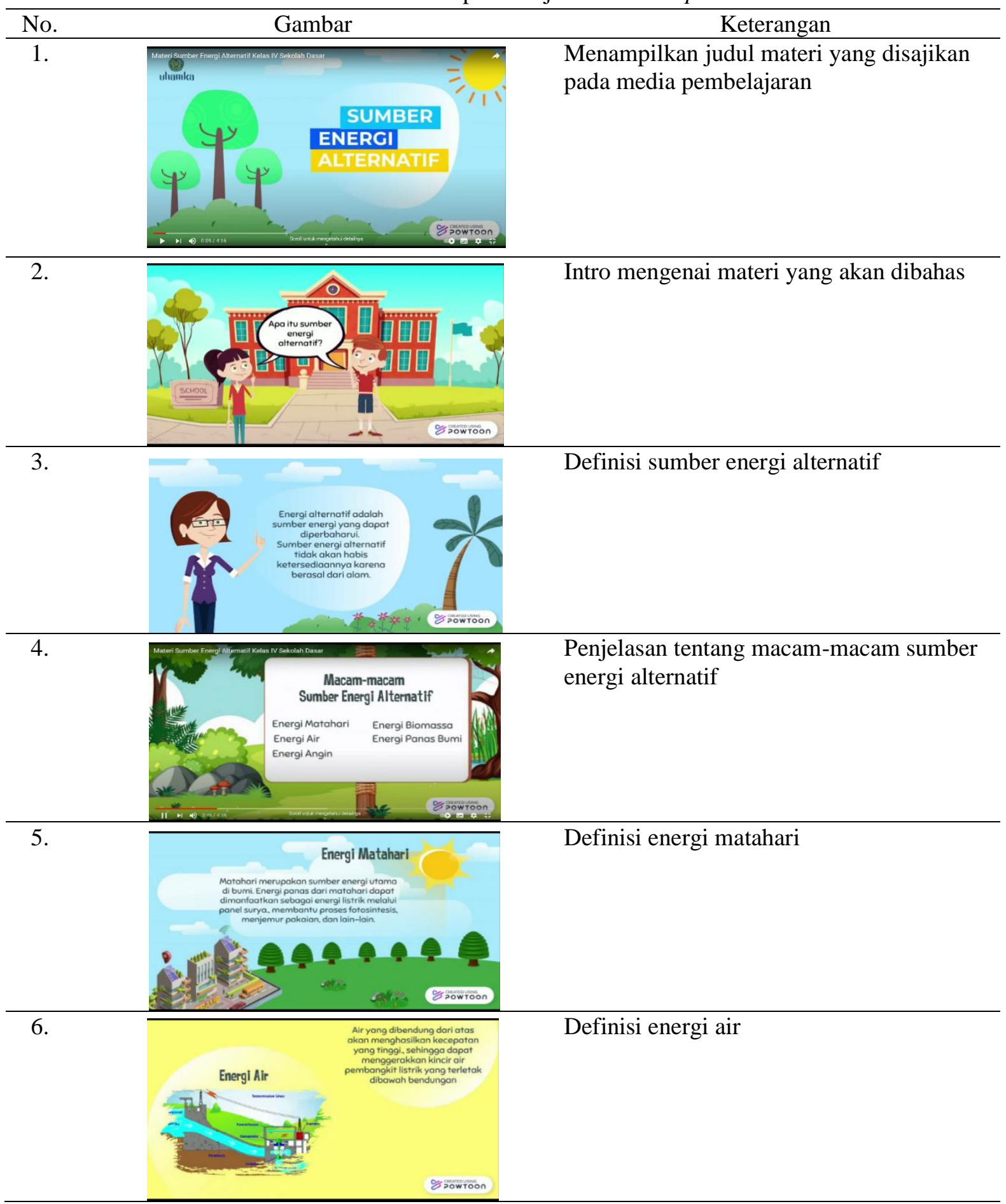


2536 Pengembangan Media Pembelajaran Video Animasi En-Alter Sources Berbasis Aplikasi Powtoon Materi Sumber Energi Alternatif Sekolah Dasar - Fifit Fitria Dewi, Sri Lestari Handayani DOI: https://doi.org/10.31004/basicedu.v5i4.1229

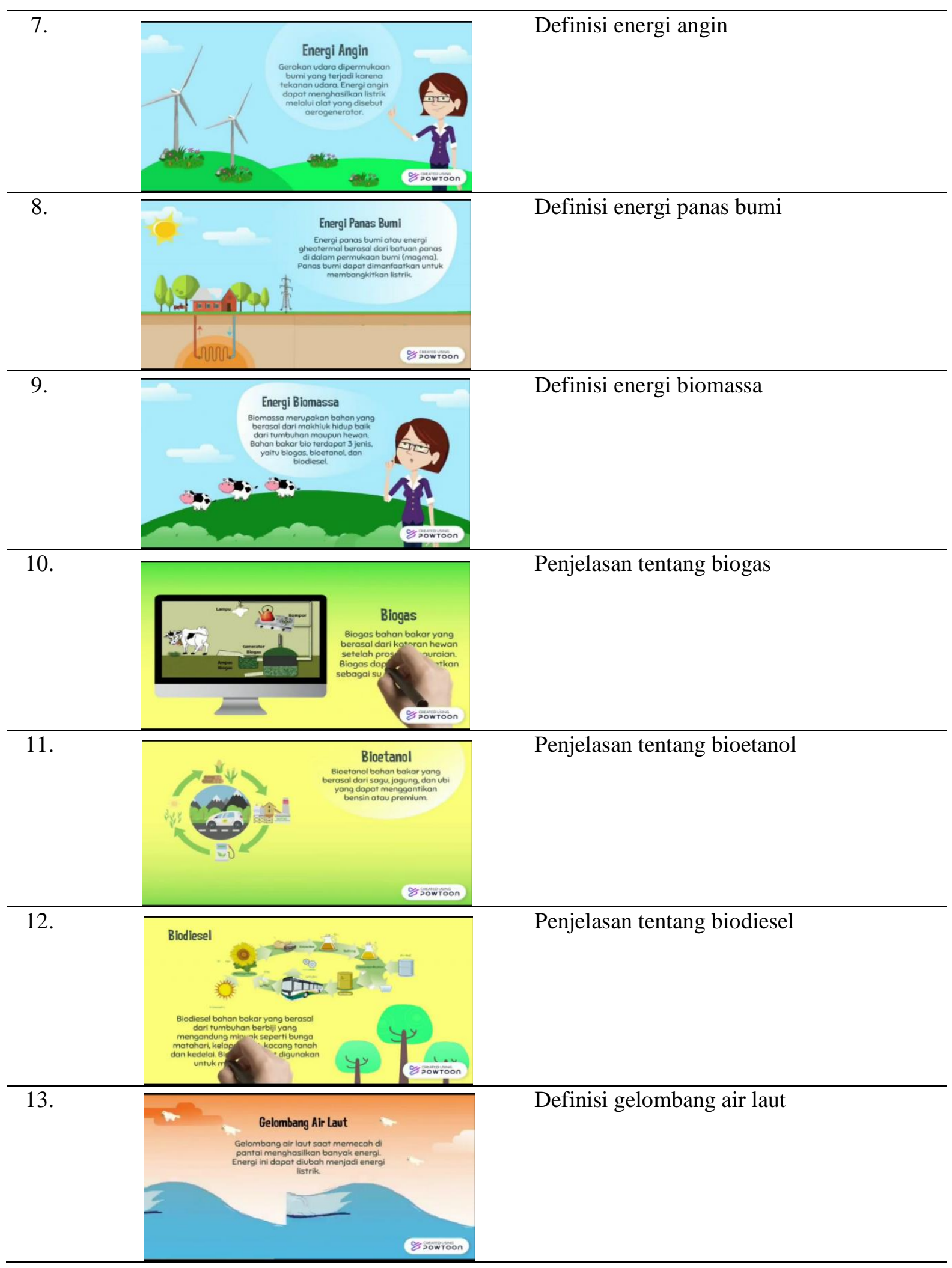


2537 Pengembangan Media Pembelajaran Video Animasi En-Alter Sources Berbasis Aplikasi Powtoon Materi Sumber Energi Alternatif Sekolah Dasar - Fifit Fitria Dewi, Sri Lestari Handayani

DOI: https://doi.org/10.31004/basicedu.v5i4.1229

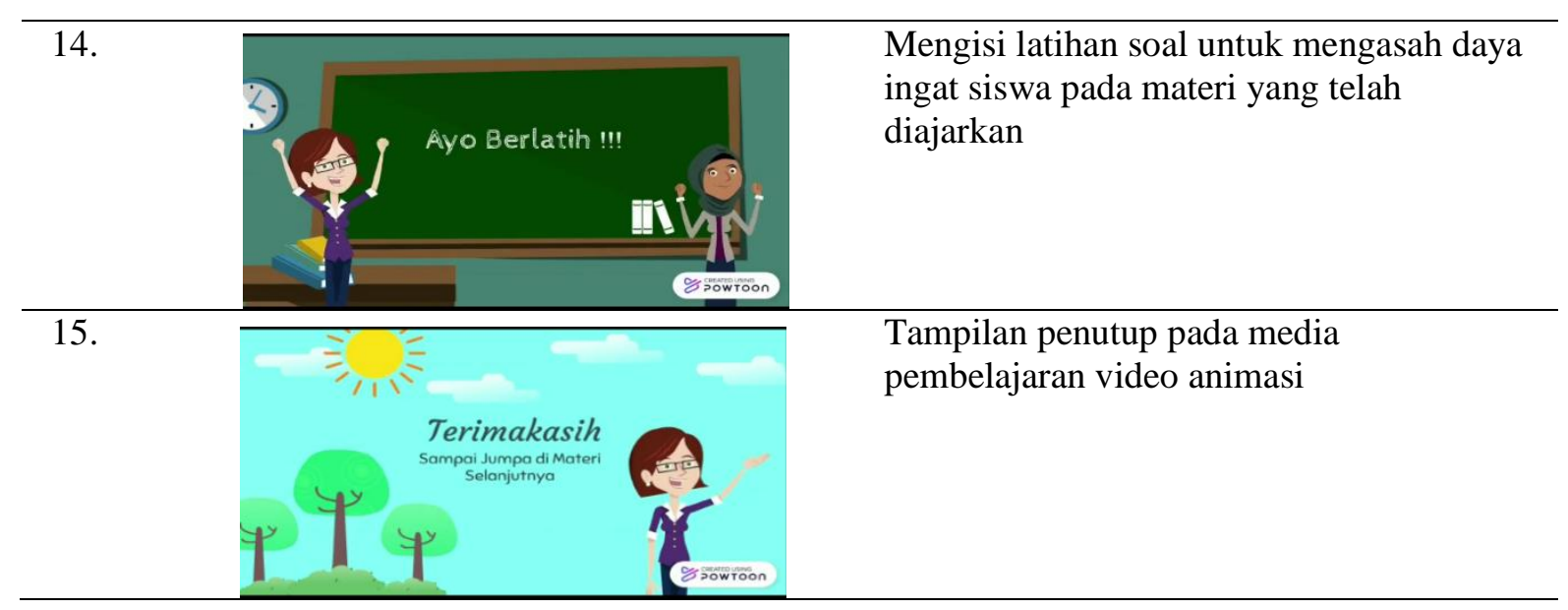

Pada tahap development ini sebelum melakukan implementasi dilakukan juga validasi oleh tim ahli untuk mengetahui media pembelajaran yang dikembangkan layak atau tidak. Peranan validasi sangat penting dalam pengembangan suatu produk. Uji validasi dilakukan oleh dua ahli materi dan dua ahli media. Proses penilaian dilakukan dengan memberikan media pembelajaran video animasi berbasis powtoon melalui WhatsApp dan google form yang siap dianalisis dan angket validasi disertai kritik dan saran atau masukan terhadap media video animasi berbasis powtoon. Masukan para ahli dapat dilihat pada tabel 4.

Tabel 3. Kritik dan masukan para ahli

\begin{tabular}{cll}
\hline No. & \multicolumn{1}{c}{ Kritik dan Saran } & \multicolumn{1}{c}{ Revisi/Perbaikan } \\
\hline 1. & $\begin{array}{l}\text { Pada awal video diberikan penjelasan materi } \\
\text { berhubungan dengan mata pelajaran apa dan } \\
\text { dapat ditemukan di tema berapa }\end{array}$ & $\begin{array}{l}\text { Menambahkan slide baru di awal, dan } \\
\text { memperbaiki sesuai saran }\end{array}$ \\
\hline 2. & $\begin{array}{l}\text { Soal evaluasi tidak perlu dimasukan kedalam } \\
\text { bagian dari video }\end{array}$ & Memperbaiki dengan menghilangkan soal evaluasi \\
\hline 3. & $\begin{array}{l}\text { Jeda materi satu dengan yang lainnya terlalu } \\
\text { cepat, beri space waktu untuk jeda materi }\end{array}$ & Memperbaiki jeda waktu yang tidak terlalu cepat \\
\hline
\end{tabular}

Berdasarkan pada table 3, saran dan masukan dari validator ahli selanjutnya peneliti merevisi media pembelajaran video animasi berbasis powtoon sesuai dengan saran. Penilaian validasi ahli materi dapat dilihat pada tabel 4.

Tabel 4. Validasi Ahli Materi

\begin{tabular}{ccc}
\hline Aspek Penilaian & Presentase $(\%)$ & Kategori \\
\hline Penyajian & $82,85 \%$ & Baik \\
\hline Bahasa & $93,33 \%$ & Sangat Baik \\
\hline Manfaat & $85 \%$ & Sangat Baik \\
\hline
\end{tabular}

Berdasarkan pada tabel 5, aspek penilaian penyajian diperoleh nilai rata-rata 82,85\% kategori baik dari total angket yang diperoleh dari pengisian dua ahli materi yang meliputi materi yang disajikan, kejelasan materi, penyampaian materi, kemudahan materi, materi yang ditampilkan sudah lengkap, penyajian gambar sesuai dengan materi. Pada aspek bahasa diperoleh skor nilai rata-rata 93,33\% yang meliputi penggunaan bahasa yang jelas, santun, dan mudah dipahami siswa, sedangkan pada aspek manfaat yaitu memperoleh nilai rata-rata $85 \%$ yang meliputi media pembelajaran mempermudah guru, dan dapat memeberikan daya tarik. Secara keseluruhan nilai rata-rata total yang diperoleh oleh dua ahli materi yaitu 85,83\% dengan kategori sangat baik, sama hal nya dengan penelitian yang dilakukan oleh Nurdiansyah (2018:4) pengembangan media 
2538 Pengembangan Media Pembelajaran Video Animasi En-Alter Sources Berbasis Aplikasi Powtoon Materi Sumber Energi Alternatif Sekolah Dasar - Fifit Fitria Dewi, Sri Lestari Handayani

DOI: https://doi.org/10.31004/basicedu.v5i4.1229

pembelajaran powtoon pada perkuliahan Pendidikan kewarganegaraan dinyatakan valid dengan nilai skor 92,5\%. Penilaian validasi ahli media dapat dilihat pada tabel 5.

Tabel 5. Validasi Ahli Media

\begin{tabular}{ccc}
\hline Aspek Penilaian & Presentase $(\%)$ & Kategori \\
\hline Penyajian & $88,75 \%$ & Sangat Baik \\
\hline Tulisan & $80 \%$ & Baik \\
\hline Bahasa & $95 \%$ & Sangat Baik \\
\hline
\end{tabular}

Berdasarkan pada tabel 5, aspek penilaian penyajian memperoleh skor nilai rata-rata $88,75 \%$ kategori sangat baik dari total angket yang diperoleh dari pengisian dua ahli media yang meliputi gambar terlihat jelas, pemilihan background, gambar, warna dan animasi, tata letak gambar dan teks, suara narator sesuai, pemilihan musik, program disajikan secara sistematis. Pada aspek tulisan diperoleh skor nilai rata-rata $80 \%$ dengan kategori baik yang meliputi penggunaan jenis huruf yang ditampilkan dan ukuran huruf, sedangkan pada aspek bahasa diperoleh skor 95\% kategori sangat baik yang meliputi penggunaan bahasa yang santun dan bahasa yang digunakan mendukung kemudahan alur materi. Secara keseluruhan nilai rata-rata total yang diperoleh oleh dua ahli media yaitu 88,33\% dengan kategori sangat baik atau layak digunakan. Hal ini sejalan dengan penelitian Fardany \& Dewi (2020:105) pengembangan media pembelajaran powtoon berbasis pendekatan saintifik layak digunakan dengan nilai rata-rata 85,06\% dalam kategori sangat layak dan efektif untuk digunakan.

Tahapan implementation yang dilakukan peneliti untuk kelas IV sekolah dasar dengan jumlah sebanyak 18 siswa. Tahap ini dilakukan untuk menguji kelayakan media yang dikembangkan. Penelitian ini dilakukan di SDN Sukamakmur 03. Hasil respon siswa dapat dilihat pada tabel 6.

Tabel 6. Hasil Respon Siswa

\begin{tabular}{ccc}
\hline Aspek Penilaian & Presentase $(\%)$ & Kategori \\
\hline Penyajian & $87,03 \%$ & Sangat Baik \\
\hline Bahasa & $85,18 \%$ & Sangat Baik \\
\hline Manfaat & $88,51 \%$ & Sangat Baik \\
\hline
\end{tabular}

Berdasarkan tabel 6, aspek penyajian diperoleh nilai rata-rata 87,03\% kategori sangat baik dari total angket yang diperoleh dari pengisian respon siswa pada media pembelajaran video animasi yang meliputi kejelasan gambar, kemenarikan gambar, warna, dan animasi, ketepatan gambar, suara dan musik terdegar jelas, kecepatan gerakan animasi, tulisan terbaca. Pada aspek bahasa diperoleh skor $85,18 \%$ kategori sangat baik yang meliputi penggunaan bahasa yang jelas, santun, dan mudah dipahami. Sedangkan pada aspek manfaat diperoleh skor $88,51 \%$ kategori sangat baik yang meliputi media yang dapat membangkitkan motivasi belajar, dapat memberikan suasana baru dalam belajar, dan mempermudah dalam memahami materi. Secara keseluruhan nilai rata-rata total yang diperoleh respon siswa adalah $86,94 \%$ dengan kategori sangat baik. Dengan demikian penelitian ini menunjukan hasil positif pada siswa pada materi sumber energi alternatif.

\section{KESIMPULAN}

Produk yang dihasilkan adalah media pembelajaran berupa video animasi berbasis aplikasi powtoon. Media pembelajaran ini menggunakan materi IPA tentang sumber energi alternatif untuk kelas IV. Penelitian ini menggunakan model pengembangan addie yang meliputi 5 tahapan yaitu analysis, design, development, implementation, and evaluation, namun pada penelitian ini peneliti membatasi sampai dengan 
2539 Pengembangan Media Pembelajaran Video Animasi En-Alter Sources Berbasis Aplikasi Powtoon Materi Sumber Energi Alternatif Sekolah Dasar - Fifit Fitria Dewi, Sri Lestari Handayani

DOI: https://doi.org/10.31004/basicedu.v5i4.1229

implementation. Pada tahap analysis peneliti melakukan analisis kebutuhan siswa, analisis materi, dan analisis perangkat yang digunakan. Pada tahap design peniliti menyiapkan konsep produk yang akan dikembangkan salah satunya yaitu storyboard. Selanjutnya tahap development, pada tahap ini peneliti merealisasikan tahapan desain yaitu storyboard ke dalam bentuk produk yang siap pakai, pada tahap ini juga dilakukan uji validasi ahli materi dan ahli media. Pada tahap berikutnya yaitu implementation, peneliti mengimplementasikan pada siswa kelas IV sekolah dasar di SDN Sukamakmur dengan jumlah 18 siswa. Hasil validasi dilakukan oleh dua ahli materi dan dua ahli media. Validasi oleh kedua ahli materi memperoleh nilai $82,85 \%$ dengan aspek penyajian, lalu pada aspek bahasa memperoleh nilai rata-rata $93,33 \%$, sedangkan pada aspek manfaat $85 \%$. Secara keseluruhan validasi ahli materi memperoleh skor total nilai rata-rata 85,83\% dengan kategori sangat baik sehingga layak digunakan. Validasi ahli media dilakukan dua ahli media, pada aspek penyajian memperoleh nilai skor $88,75 \%$, pada aspek tulisan memperoleh nilai rata-rata $80 \%$, sedangkan pada aspek bahasa memperoleh nilai rata-rata 95\%. Secara keseluruhan validasi ahli media memperoleh skor total nilai rata-rata $88,33 \%$ kategori baik. Hasil respon siswa memperoleh skor $82,85 \%$ pada aspek penyajian, $93,33 \%$ aspek bahasa, dan $85 \%$ aspek manfaat. Nilai skor secara keseluruhan pada hasil respon siswa 86,94\% dengan kategori sangat baik, sehingga media pembelajaran video animasi berbasis powtoon pembelajaran IPA materi sumber energi alternatif layak digunakan.

\section{UCAPAN TERIMAKASIH}

Peneliti mengucapkan terimakasih kepada Allah SWT, keluarga, teman sejawat yang telah memberikan semangat, dan Universitas Muhammadiyah Prof. Dr. Hamka, terutama pada ketua prodi PGSD yang telah memfasilitasi peneliti, kepala sekolah beserta guru, dan siswa kelas IV atas kerjasamanya dalam menyelesaikan penelitian ini. Selanjutnya peneliti ucapkan terimakasih kepada dosen pembimbing atas bimbingan dan arahannya dalam pembuatan jurnal.

\section{DAFTAR PUSTAKA}

Aprianty, D., \& Wiyono, K. (2021). Pengemabngan Multimedia Interaktif Pada Dan Segitiga Di Sekolah Dasar. 30, 1-13.

Asyhari, A. (2016). Pengembangan Media Pembelajaran Berupa Buletin Dalam Bentuk Buku Saku Untuk Pembelajran Ipa Terpadu. Jurnal Ilmiah Pendidikan Fisika Al-Biruni, 5.

Awalia, I., Pamungkas, A. S., \& Trian, P. (2019). Pengembangan Media Pembelajaran Animasi Powtoon Pada Mata Pelajaran Matematika Di Kelas Iv Sd. 10, 49-56.

Cahyadi, R. A. H. (2019). Pengembangan Bahan Ajar Berbasis Addie Model. Halaqa: Islamic Education Journal, 3, 36.

Fadhli, M. (2015). Pengembangan Media Pembelajaran Berbasis Video Kelas Iv Sekolah Dasar. Jurnal Dimensi Pendidikan Dan Pembelajaran, 3, 24-29.

Faisal, E. El. (2016). Pengembangan Bahan Ajar Berbasis Muatan Lokal Pada Mata Kuliah Pendidikan Kewarganegaraan. 113-126.

Fardany, M. M., \& Dewi, R. M. (2020). Pengembangan Media Pembelajaran Powtoon Berbasis Pendekatan Saintifik Pada Mata Pelajaran Ekonomi. Jurnal Pendidikan Ekonomi (Jupe), 8, 107.

Firdaus Ahmad, D. M. (2021). Jurnal Basicedu. Jurnal Basicedu, 5.

Garsinia, D., Kusumawati, R., \& Wahyuni, A. (2020). Pengembangan Media Pembelajaran Video Animasi Menggunakan Software Powtoon Pada Materi Spldv. Jurnal Riset Pendidikan Dan Inovasi Pembelajaran Matematika (Jrpipm), 3, 45. 
2540 Pengembangan Media Pembelajaran Video Animasi En-Alter Sources Berbasis Aplikasi Powtoon Materi Sumber Energi Alternatif Sekolah Dasar - Fifit Fitria Dewi, Sri Lestari Handayani

DOI: https://doi.org/10.31004/basicedu.v5i4.1229

Hakim, M. L. (2019). Development Of Video Media In The History Of Islamic Culture History. 06(02), 309.

Irwan, F., Santyasda, I. W., \& Tegeh, I. M. (2014). Pengembangan Multimedia Interaktif Berbasis Self Regulated Learning Dengan Model Addie Untuk Meningkatkan Prestasi Belajar Seni Budaya Bagi Siswa Kelas Vii Smp Negeri 3 Mendoyo. E-Journal Program Pascasarjana Universitas Pendidikan Ganesha, 4, 1-10.

Khuluqo, I. El. (2017). Belajar Dan Pembelajaran Konsep Dasar Metode Dan Aplikasi Nilai-Nilai Spiritualitas Dalam Proses Pembelajaran. Pustaka Pelajar.

Nurdiansyah, E. (2018). Pengembangan Media Pembelajaran Berbasis Powtoon Pada Perkuliahan Pendidikan Kewarganegaraan. Jurnal Civics: Media Kajian Kewarganegaraan, 15.

Ranie, F. (2018). Pengembangan Media Pembelajaran Video Animasi Powtoon Pada Mata Pelajaran Pelayanan Penjualan Di Smk Ketintang Surabaya. Jurnal Pendidikan Tata Niaga ( Jptn ), 06, 145-150.

Rejeki, R., Adnan, M. F., \& Siregar, P. S. (2020). Pemanfaatan Media Pembelajaran Pada Pembelajaran Tematik Terpadu Di Sekolah Dasar. Jurnal Basicedu, 4, 337-343.

Suryani, N. (2016). Pengembangan Media Pembelajaran Sejarah Berbasis It. Sejarah Dan Budaya: Jurnal Sejarah, Budaya, Dan Pengajarannya, 10, 186.

Sutarsih, W. A., \& Hermanto. (2019). Pengembangan Rancangan Media Pembelajaran Berbasis Powtoon Pada Materi Teks Prosedur Kelas Vii Di Smp Negeri 3. Jurnal Pendidikan Bahasa Dan Sastra Indonesia, Fakultas Keguruan Dan Ilmu Pendidikan, Universitas Ahmad Dahlan Yogyakarta.

Tafonao, T. (2018). Peranan Media Pembelajaran Dalam Meningkatkan Minat Belajar Mahasiswa. Jurnal Komunikasi Pendidikan, 2, 103.

Wisada, P. D. (2019). Pengembangan Media Video Pembelajaran Berorientasi Pendidikan Karakter. Journal Of Education Technology, 3, 141.

Yuanta, F. (2019). Pengembangan Media Video Pembelajaran Ilmu Pengetahuan Sosial Pada Siswa Sekolah Dasar. Trapsila: Jurnal Pendidikan Dasar, 1, 92. 